\title{
Oral Mucosal Immune Tolerance Versus Oral Immune Silencing: Mini Review
}

\author{
Ibrahim M. S. Shnawa \\ College of Biotechnology, University of KASIM, Kasim, Babylon Governerate, Iraq
}

\section{Email address:}

ishnawa@yahoo.com

\section{To cite this article:}

Ibrahim M. S. Shnawa. Oral Mucosal Immune Tolerance Versus Oral Immune Silencing: Mini Review. American Journal of Biomedical and Life Sciences. Special Issue: Advances in Oral Immunity. Vol. 3, No. 4-1, 2015, pp. 7-9. doi: 10.11648/j.ajbls.s.2015030401.13

\begin{abstract}
Oral mucosal tolerance a phenomenon among others in the common mucosal immune system. The mechanisms behind which are multiple. Three main opinions are being raised up .First ,tolerant cells emerged within the gut mucosa and migrates to oral mucosa suppressing immune function, the second holds that tolerant cells evolved with in the sublingual salivary glands and functions insitue and the third, however, considered tolerance as an active immune processes marked with hypersensitivity and antibody formation.
\end{abstract}

Keywords: Stomium, Oral, Mucosa, Mucosal Immune Response, Oral Mucosal Tolerance, Immune-Silencing

\section{Introduction}

Tolerance is an immune phenomenon, in which the immune response outcomes are being reduced or abolished following continual low or high grade of antigen concentrations encountering the immune system functional cells[1].

\section{Stomium as an Immune Compartment}

The stomium or the "Oral Cavity" is considered as a compartment of mucosal immune nature, it belongs to gut associated lymphoid tissue (GALT) in a sense and as a part of cranial-oral-nasal-associated lymphoid tissues(CONALT) in other sense .It consist of mucosa with its own different parts ,salivary glands and tonsils .It may covers an effector and inductive sites of the common mucosal immune system[2].

\section{Oral Mucosal Immune Responses}

There are somewhat several types of immune responses that are initiated within the oral mucosal compartment. These responses are like; Humoral mucosal and cellular mucosal immune responses in one hand and oral mucosal tolerance on the other hand. Humoral and cellular systemic a consequences of these oral mucosal immune responses. These besides the oral immune silencing events [2]

\section{Migratory Immune Cells in Relation to Immune Functions}

Migratory dendritic cells, langerhanse cells as well as the antigen primed lymphocytes are recruited to the oral microenvironment which are preprogrammed to establish the state of the oral mucosal tolerance[3].

\section{Systemic Immune Tolerance}

Systemic immune tolertance can be central genetic or peripheral acquired .The peripheral is acquired and may be induced via low dose toleragen (An antigen that induced tolerance state)or it can be intiated with the exposure to high dose toleragen. Tolerance persist whenever the toleragen is exists in contact with the functional immune cells (The immune committed cells).If it is vanished and not being in such contact, tolerance state can be broken. Tolerance is merely a cellular issue rather than whole being immune system of a certain vertebrate animal. Thus there are B cell tolerance and $\mathrm{T}$ cell tolerance. $\mathrm{T}$ cell tolerance is being easier to induce than that of $\mathrm{B}$ cells. The mechanisms behinds the systemic immune tolerance are, clonal cell deletion, clonal cell anergy, Treg activity, and clonal negative selection $[4,5,6,7]$. 


\section{Oral Mucosal Tolerance}

Three points of views are being evident when, one begins to tackle the topic of oral mucosal immune tolerance. First, constitute the theme of general immune tolerance ,the second is that tolerant cells initiated in gut mucosa and migrated to the oral cavity and performs their effects there, while the third, however state that the oral mucosal tolerance represents a state of an active process including delayed type hypersensitivity and antibody formation. It is initiated by the continual exposure of the oral mucosal surfaces to food and microbial related antigens throughout mastication, drinking, and/or sucking. This state needs pre-requiests and laid on mechanisms . The pre-requiest are, normal immune function, vived normal commensal microflora ,persistent antigen presence, antigen specific and it diminished with time. The mechanisms are; clonal deletion of $\mathrm{T}$ cells, $\mathrm{T}$ cell apoptosis, anergy, Treg .cell activity,Th3 cell function as well as dendritic cell activity and $\mathrm{Sc} \operatorname{IgA}[8,9,10]$.

\section{Oral Mucosal Immune Silencing}

Oral mucosal Langerhans cells may constitutively express high inhibitory B7-H molecules on their surfaces with further up -regulation through stimulation by microbes or their byproducts .Thus ,immune-silencing appear to be a mechanism among a number of mechanisms for interpretation of oral mucosal tolerance[11].

\section{Systemic Immune -Suppression}

It is a sort of systemic interference with initiation or expression of an immune response. On the conterory to tolerance which is an antigen specific, immune-suppression is of both specific and non specific nature. It concerns with the immune system as whole. Systemic immune suppression may be intiated through exposure ton cytotoxic drugs, whole body irradiation and or massive loss of lymphoid or tissues harbouring the lymphomyeloid mononuclear cell system in cases of nonspecific immune suppression. Non-specific immune suppressants are more effective in blocking primary rather than secondary immune responses. Though in cases of Specific immunosuppression, three immune modalities can be helpful in attaining it. Namely, Antibody as an antiimmunogen, antibody as an antireceptor anti-lymphocyte serum. This prolongs thsurvival of allografts, reduces antibody formation in primary immune response to many $\mathrm{T}$ cell dependent antigens, if administered prior to the injection of the antigen $(12,13,14,15)$

\section{Oral Mucosal Immune Suppression}

Under the selective pressure of a rather un -rationalized use of antimicrobial drugs, it happened most frequently that the immune vagor of the mucosal immune committed cells is weakened or suppressed .Thus, yeast opportunist overgrown and prevail therein the oral mucosal compartments leading to a super-infection state known as thrush. It is non-antigen specific and general covering the whole oral cavity[16].

\section{Differentiation/ Delination}

To discriminate between such allied oral immune mediated conditions, a comparison was made and tabulated in Table-1.

Table 1. Tolerance and the allied immune mediated conditions.

\begin{tabular}{lllll}
\hline Feature & Immune suppression & $\begin{array}{l}\text { Systemic } \\
\text { Tolerance }\end{array}$ & $\begin{array}{l}\text { immune } \\
\text { Oral mucosal } \\
\text { Tolerance }\end{array}$ & $\begin{array}{l}\text { Oral mucosal } \\
\text { Silencing }\end{array}$ \\
\hline Involvement & Whole immune system & Immune cells & Immune cells & Immune cells \\
Cell nature & - & T and B & T reg,DCs,Th3 & Lengerhans \\
Role of antigen & - & antigen specific & antigen specific & antigen specific \\
Immune function & $+/-$ & full immune & full immune & need immune \\
Commensal flora & $?$ & $+/-$ & needed & Lengerhans \\
Mechanisms & stop functions & Anergy & migratory DC & Th3,antibody \\
& & Clonal delition & & \\
& & T reg, immature & & \\
& Lymphocyte, and lymph & & \\
& & Vessel & & \\
& &
\end{tabular}

\section{Applications}

Systemic immune tolerance gains some medical application like husband -wife differences in $\mathrm{Rh}$ antigens/antibodies $\mathrm{Rh}$ negative wife to $\mathrm{Rh}$ positive husband bearing fetus of $\mathrm{Rh}$ positive trait need to given the $\mathrm{D}$ substance .Respiratory allergy to common pollen allergens can be treated by desensitization therapy of low doses of the allergens .Oral mucosal tolerance have some other applications like; Sublingual immunotherapy in which ,the allergen solution or tablets are applied to the sublingual mucosa to induce allegen specific tolerance[3].

\section{Concluding Remarks}

Stomium is a site of rather high bacterial colonization and frequent contacts with food and drink allergens ,acute oral inflammations and allergies are rarely seen. This because that oral mucosal immune tolerance is predominant in it .Dendritic cells and T cell sub types interplayed a key role in oral mucosal tolerance. 


\section{References}

[1] Playfair JHL ,Chain BM 2001,Immunology at a Glance, $7^{\text {th }}$ ed,Blackwell Scientific.

[2] Walker DM 2004 ,Oral mucosal immunology ,An Overview ,Ann .Acad .Singapore 33(S):27S-30S.

[3] Novak N ,Haberstok J ,Bieber T ,Allam J-P 2008, The immune privilege of the oral mucosa ,Cel,1 14(5):1912-198.

[4] Schwartz RH, Mueller DL,2003,Immunological Tolerance ,In Pual W ed .Fundamental Immunology , $5^{\text {th }}$ ed. ,Lippincott Williams and Wilkins,Philadelphia,901-934.

[5] Kisielow P 1998, Tolerance,central,In Delves PJ ,Roitt I ,Encyclopedia of Immunology vol.4, Academic Press ,New York, 2352-2361.

[6] Scott BW 1998,Tolerance,Peripheral,In Delves PJ,Roitte I ed ,Encyclopedia of Immunology Vol.4,Academic Press ,New York,2362-2367.

[7] Weigle WO 1998,Tolerance,Models,In Delves ,PJ, Roitte ,I ed. ,Encyclopedia of Immunology ,Vol 4,Academic Press,2359-2361.

[8] Weiner HL,1998,Oral tolerance,In Delves PJ,Roitte I ed. ,Encyclopedia of Immunology ,Vol.4,Academic Press, 1893-1899.

[9] Faria AMC ,Mucida D, MaCafferty D-M ,Jsuji $\mathrm{NM}$,Verhasselt V,2012,Tolerance and inflammation at the gut,Clin.Developmental.Immunol.2012:1-3.

[10] Pabst O, Mowat AM,2012,Oral tolerance to food protein ,Mucosal Immunol.,5:232-239.

[11] Allam JP ,Peng W-M ,Appel T, Wenahoefer M, Niederhagen B, Bieber T ,Novak N ,2008,Toll-like receptor 4 ligation enforces toleragenic properties of oral mucosal langerhans cells,J.Aller.Clin.Immunol.,121:368-374.

[12] Hotchkiss R,Monnert G,Payen D, 2013,Immunosuppression in sepsis: a novel understanding of disorder and ne therapeutic approach,Lancet infectious Diseases,13(3):260-268.

[13] Bhorade S M,Stern E,2009,Immunosuppression for lung transplantastion,Proc. Thor.Soc. ,6(1):41-53.

[14] Male D ,Brostoff I, Roth D B, Roitt I,2006,Immunology, $7^{\text {th }}$ ed., Mosby ,Elsever ,Canada,311-24,336-338.

[15] Brooks GF, Carroll KC ,Butel JS, Mietzner TA,2013,Jawetz,Melnick,and Adelbergs Medical Microbiology, $26^{\text {th }}$ ed, Macgraw-Hill ,Lange ,New York.,380381. 